\title{
REMARKS ON THE EMERGENCE OF DANIEL $1^{*}$
}

\begin{abstract}
Summary: Chapter 1 of the Book of Daniel comprises a complex material, which emerged in various successive editorial steps. This paper argues that at least three different hands had contributed to its formation. The growth of the material can clearly be traced back to the emergence of the core material of verses 5a.8-16, and its gradual supplementation with verses 3-7, 17-21 and verses 1-2.
\end{abstract}

Key words: Book of Daniel, Second Temple literature, court story, Hebrew Bible

Scholars often regard the first chapter of the Book of Daniel as a nicely unified introductory narrative to the following court tales or to the entire book. John Goldingay, for example, devoted considerable efforts to demonstrate the strict concentric structure of the chapter as a unified whole. ${ }^{1}$ John Collins' opinion has also changed in this direction. In 1984 he maintained that "verses 8-16 constitute an independent story", a decade later, however, in his magisterial commentary he simply assumes that the chapter "is a coherent narrative". Although he raises the possibility that "vv. 8-16 could have circulated independently", and that the status of Daniel's three companions is somewhat ambivalent throughout the chapter, he nevertheless tends to argue for the unity of chapter $1 .^{3}$

Klaus Koch, on the contrary, calls attention to certain developments in the material of the chapter. For various reasons he postulates verses $1.3-6 a .8-17$ as the "aramäische Vorstufe" of the chapter, which was later augmented with the remaining

\footnotetext{
* For the grammatical revision of the paper, the author is indebted to Dr. Ibolya Balla.

${ }^{1}$ GoldingaY, J.: Daniel [Word Biblical Commentary 30]. Dallas 1989, 8-12, see also Newsom, C. A.: Daniel: A Commentary. Louisville 2014, 39.

${ }^{2}$ Collins, J. J.: Daniel with an Introduction to Apocalyptic Literature [Forms of the Old Testament Literature 20]. Grand Rapids 1984, 44.

${ }^{3}$ Collins, J. J.: Daniel [Hermeneia: A Critical \& Historical Commentary on the Bible]. Minneapolis 1993,130 .
} 
material by the redactor of chapters $2-6 .{ }^{4}$ Recently, Michael Segal has arrived at similar conclusions when commenting on the Entstehungsgeschichte of the chapter. He holds that the basic material of the chapter is found in verses 5a.8-16, supplemented with the surrounding verses to form an introduction to chapters $2-6 .{ }^{5}$

In this short contribution I intend to make some comments which might be helpful in arguing for the gradual formation of Daniel chapter 1. My opinion is based on observations that different portions of the text betray different approaches and compositional techniques of the author(s).

\section{INTERTEXTUAL BACKGROUND}

There is an obvious difference between Dan 1:8-16 and the rest of the chapter in their use of other written material. It is an oft-repeated fact that Dan 1:2b strongly depends on 2Chron 36:7. The verse "The Lord let King Jehoiakim of Judah fall into

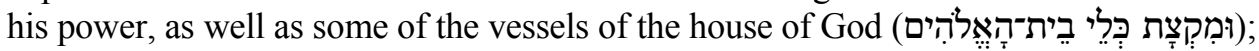
these he brought (וַיביביאם) to the land of Shinar, and placed the vessels in the treasury

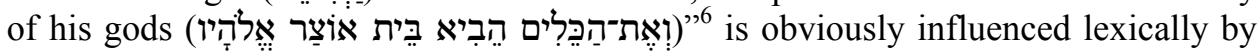
the Chronicler's comment: "Nebuchadnezzar also carried (הבריא) some of the vessels

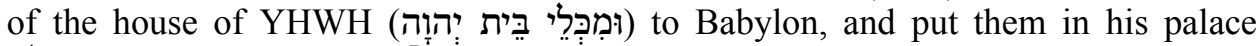

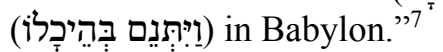

Scholars also note that the use of the enigmatic temporal phrase "in the third

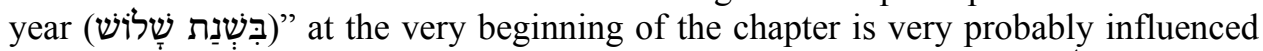
by 2Kings 24:1: "Jehoiakim became his servant for three years (שָׁלש שָׁנים); then he turned and rebelled against him.,"

James Montgomery argued that there are intertextual connections, too, between Dan 1:5 and the Joseph story (Gen 42:25). ${ }^{9}$ Although Segal is reluctant to accept this parallel, and holds that the connections are very loose between these verses, ${ }^{10}$ in view of their common literary genre one cannot exclude the influence of the Joseph story on Daniel $1 .{ }^{11}$ In verse 5 , a further intertextual influence can be detected. It is narrated

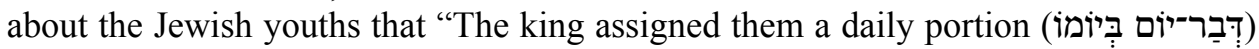

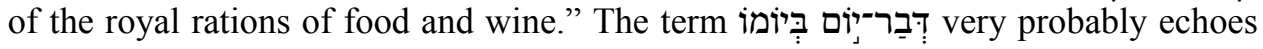

${ }^{4}$ Koch, K.: Daniel [Biblischer Kommentar AT 22/1]. Neukirchen 1986, 18-21; similarly HARTMAN, L. F. - Di Lella, A. A.: The Book of Daniel [The Anchor Yale Bible Commentaries 23]. Garden City 1978, 133.

${ }^{5}$ Segal, M.: Dreams, Riddles, and Visions. Textual, Contextual, and Intertextual Approaches to the Book of Daniel [Beihefte zur Zeitschrift für die alttestamentliche Wissenschaft 455]. Berlin 2016, 22-26.

${ }_{7}^{6}$ Biblical references in English follow the New Revised Standard Version [NRSW].

${ }^{7}$ See the commentaries, ad loc.

${ }^{8}$ See the commentaries, ad loc., and SEgAL (n. 5) 26-31.

${ }^{9}$ Montgomery, J. A.: A Critical and Exegetical Commentary on the Book of Daniel [International Critical Commentary]. Edinburgh 1927, 128.

${ }^{10}$ Segal (n. 5) 17-18.

${ }^{11}$ See e.g., XeRAVITS, G. G.: Interreligiosity as a Literary Fiction in the 'Court Tales' of the Old Testament. In LosonczI, P. - XerAvits, G. G. (eds.): Reflecting Diversity: Historical and Thematical Perspectives in the Jewish and Christian Tradition [Schnittpunkte/Intersections 1]. Wien 2007, 1-11. 
2Kings 25:30 and Jer 52:34, where king Jehoiachin is reported to obtain a daily allowance (דָּבְרָיוֹם בְּיוֹמוֹ) from the Babylonian king after his release from captivity. ${ }^{12}$

Beside these scriptural reminiscences certain parts of the chapter provide allusions to the Danielic oeuvre as such. First, verse 2 might refer to the conflict of

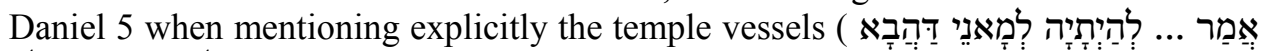
, 5:2). Second, with the mention of King Cyrus the author of 1:21 on the one hand recalls the end of the age of the Exile, and on the other, connects the material to chapter 6 (which ends by referring to the first year of Cyrus), or chapter 10 (the introductory statement of which places that

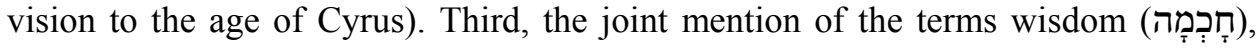

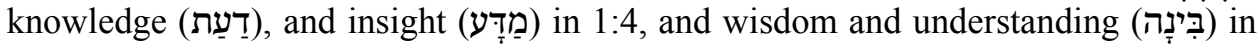
1:20 evokes various passages from Daniel 1-6, especially 2:21b: "he gives wisdom

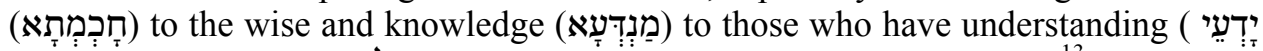

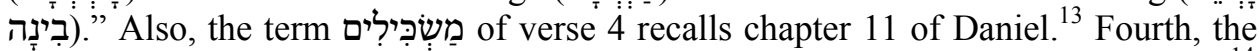
Babylonian court officials mentioned in 1:20 appear repeatedly in chapters 2, 4 and 5. ${ }^{14}$

Interestingly enough, verses $8-16$ do not abound in textual allusions. The only possible intertextual connection of this passage with other scriptural material might

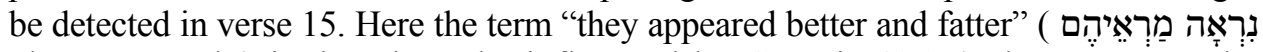

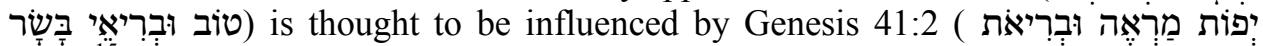

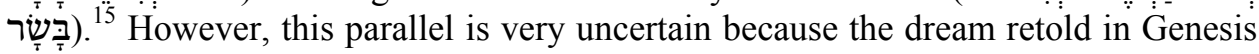
41 has a completely different subject than the one in Daniel. Here the lexical correspondence between the texts does not display an intentional interconnecting on behalf of the author of Daniel 1.

In summary, verses 1-7 and 17-21 deliberately use other scriptural material and elements reminding one of other parts of Daniel. On the contrary, verses 8-16 do not display any probable intertextual references.

\section{THE PLOT OF THE STORY}

The story of Daniel 1 nicely fits into its genre, the court story, following its familiar scheme of introduction - conflict - solution - conclusion. ${ }^{16}$ It seems, however, that two different stories had been interwoven to form the material of the chapter.

${ }^{12}$ See the commentaries, ad loc.

${ }^{13}$ See CoLLINS: Daniel with an Introduction (n. 2) 44

${ }^{14}$ See furthermore KOCH (n. 4) 44-45 and 70-71.

15 See Collins: Daniel (n. 3) 144.

${ }^{16}$ XERAVits (n. 11), see furthermore the detailed analyses of the genre in e.g. HUMPHREYs, W. L.: A Life-Style for Diaspora: A Study of the Tales of Esther and Daniel. Journal of Biblical Literature 92 (1973) 211-223; MEINHOLD, A.: Die Gattung der Josephgeschichte und des Esterbuches: Diasporanovelle. Zeitschrift für die Alttestamentliche Wissenschaft 87 (1975) 306-324 and 88 (1976) 79-93; NIDITCH, S. DoRAN, R.: The Success Story of the Wise Courtier: A Formal Approach. JBL 96 (1977) 179-193; WiLls, L. M.: The Jew in the Court of the Foreign King [Harvard Dissertations in Religion 26]. Minneapolis 1990; WiLls, L. M.: The Jewish Novellas. In MORGAN, J. R. - StOnEMAN, R. (eds.): Greek Fiction. The Greek Novel in Context. London 1994, 223-238. 
Verses 5a.8-16 appear in this context as an independent narrative. The king's order to assign the Jews food and wine from the royal supplies (1:5a) forms an introduction to the story. Daniel's refusal of accepting it (1:8) marks the conflict. The solution is related in verses 9-14, in which by divine help and by Daniel's natural skilfulness he and his companions do not fail during the conflict. Finally, as a conclusion $(1: 15-16)$ it becomes obvious that they successfully solve the problem they face in the foreign court, and the pagan officer acknowledges and tolerates their life-style.

From the Babylonian perspective the accent of the story lies on the youths' physical appearance, whereas from the Jewish perspective the accent is on their purity, as verse 9 explicitly states: "Daniel resolved that he would not defile himself

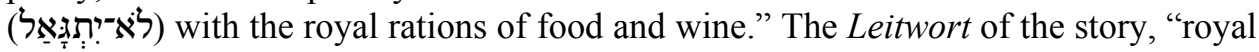

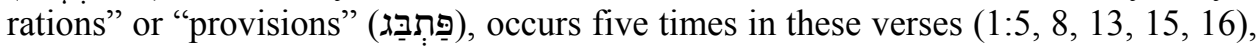
but nowhere else in the rest of the chapter outside the context of 1:5a.8-16. Also, outside this context nothing is said about the physical appearance of the Jewish protagonists, except in 1:4a, where it is a precondition for their selection that they must be "without physical defect and handsome." This, however, remains an isolated remark.

The rest of the chapter displays completely different intentions. The main pagan antagonist here is King Nebuchadnezzar, instead of the officials of the other story. $\mathrm{He}$ is the one who commands the selection of the Jewish nobles and orders their education. The latter centres on their intellectual training, and this perspective dominates verses 3-7 and 17-21. The youths are said to be "versed in every branch of wisdom,

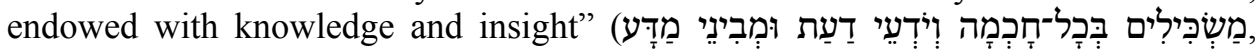
$1: 4 b)$. This aspect remains unnoticed until verse 17 , which states that in the course of their training they obtain from God "knowledge and skill in every aspect of literature

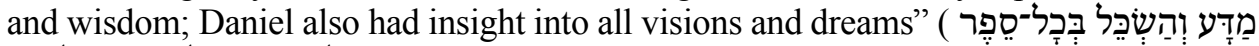

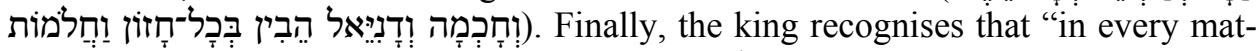

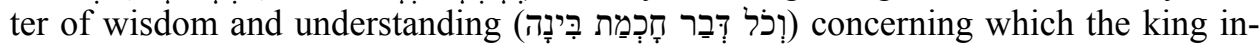
quired of them, he found them ten times better than all the magicians and enchanters

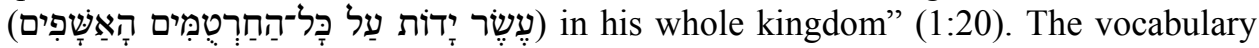
used in verses $4 \mathrm{~b}, 17$ and 20 for characterising the youths is predominantly sapiential. This sapiential perspective - which is completely in line with the other chapters of Daniel - is, however, totally missing from verses $8-16$. It is also striking that without $1: 8-16$ the chapter lacks a real conflict situation. The plot of 1:3-7, 17-21 is linear: the intelligent youths are being selected, they advance in learning, and finally they prove to be superior even to the pagan officers of the king.

Finally, a further detail deserves some comments here, viz. that the chapter relates the divine intervention twice, in verses 9 and 17. It is introduced similarly by

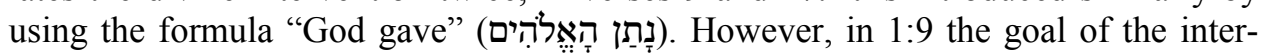
vention is that Daniel may "receive favour and compassion from the palace master" concerning his special diet, whereas in 1:17 God gives understanding to Daniel and his companions.

In summary, there are good reasons to suppose that Daniel 1:5a.8-16 constitutes an originally autonomous story, which emerged independently from the Danielic 
stories. Its expansion with verses 3-7, 17-21 took place when it was integrated into the emerging Danielic oeuvre. ${ }^{17}$

\section{FURTHER DISCREPANCIES IN THE TEXT OF THE CHAPTER}

The conclusion above might be strengthened by the fact that the position of Daniel's three companions is somewhat loose in $8-16$. This story has only one real protagonist: Daniel. The names of Hananiah, Mishael and Azariah are mentioned in this context only in verse 11, and their appearance does not contribute to the development of the story, ${ }^{18}$ simply speaking, their appearance here seems to be a secondary gloss. On the other hand, their presence is much better contextualised in 3-7, 17-21. The narrative speaks about the selection of "some of the Israelites", and their names appear in verses 6,7 and 19 . In view of the fact that the material of 3-7, 17-21 consistently refers to other chapters of Daniel, the author's intention here is to set the protagonists of the various successive chapters of Daniel on stage. Their insertion into verse 11 serves to strengthen the unity of the interconnected material.

Another important discrepancy of the chapter can be detected between verses 1-2 and 3. The first two verses serve to provide a general historical background for what follows. ${ }^{19}$ In this case, the author envisions the capture of Jerusalem by Nebuchadnezzar and the transfer of the temple vessels into Babylon. Verse 3 relates the royal order of selecting youths from among the Israelite elite for the service of the palace. Yet, there are no hints about the deportation of the Israelites: 1:1-2 speaks only about the transfer of the holy objects but not about that of persons, whereas this is an obvious fact for verse 3. Thus, it seems that the first two verses of the chapter emerged independently from the rest of the chapter, and their purpose could probably have been to introduce the entire Danielic cuvre. The intention of these verses - as Klaus Koch has demonstrated - is to present the "Wechsel der malkut von Jerusalem nach Babel" ${ }^{20}$ In doing so, these verses anticipate the theme of translatio imperii dominant throughout chapters $2-7$ of Daniel. ${ }^{21}$

${ }^{17}$ Contrarily to P. L. REDDIT (Daniel 9: Its Structure and Meaning. Catholic Biblical Quarterly 62 [2000] 242), who holds that verses 8-16 are a later addition to the rest of the chapter.

${ }^{18}$ On the problem of the presence of the companions, see KOCH (n. 4) 19-20.

${ }^{19}$ This is the general custom of the chapters in Daniel; all of the successive independent stories are placed in various concrete historical periods by identifying the specific kings under whom the events retold are thought to have taken place.

${ }^{20} \mathrm{KOCH}$ (n. 4) 36-42.

${ }^{21}$ See esp. KRATZ, R. G.: Translatio imperii: Untersuchungen zu den aramäischen Danielerzählungen und ihrem theologiegeschichtlichen Umfeld [Wissenschaftliche Monographien zum Alten und Neuen Testament 63]. Neukirchen 1991. 


\section{CONCLUSIONS}

The remarks above, I believe, have shed light on the gradual emergence of Daniel, chapter 1 . The material of $5 \mathrm{a} .8-16$ can be found at the beginning of the process, a short court story about the success of - probably only one - young Jew in the court of the Babylonian king. As a second step, when this story was connected to the emerging Danielic ouvre, it was supplemented with 3-7, 17-21, a text closely contextualised to suit the material of the following chapters. Very probably during this step the companions of Daniel were inserted into the original story, into verse 11. Finally, another redactor supplemented the chapter with verses $1-2$, reflecting one of the main theological stances of the book.

Géza G. Xeravits

Faculty of Reformed Theology

J. Selye University Komárno

Slovakia 